\title{
ANALISIS KINERJA PENEGAKAN HUKUM DALAM PENANGANAN KASUS PERDAGANGAN ILLEGAL SATWA YANG DILINDUNGI DI PROVINSI KALIMANTAN BARAT
}

(Analysis of Law Enforcement Performance in Handling of Illegal Trading of Protected Animals in West Kalimantan Province)

\author{
Rachmad $^{1}$, Hari Prayogo ${ }^{2}$, M. Sofwan Anwari ${ }^{2}$ \\ ${ }^{1}$ Direktorat Reserse Kriminal Khusus Polda Kalimantan Barat \\ ${ }^{2}$ Program Studi Magister Ilmu Kehutanan Fakultas Kehutanan Universitas Tanjungpura Jalan \\ Imam Bonjol Pontianak 78124 \\ e-mail: mamadaraw2@gmail.com
}

\begin{abstract}
This research is motivated by the high cases of illegal trade of protected wildlife in West Kalimantan Province. Animal trade tends to be endangered and included in the endangered list. Actions of animal trade that still occur in West Kalimantan Province indicate the low level of law enforcement and weak supervision by related parties in combating cases of protected animal trade. The purpose of this study is to examine the factors causing the occurrence of illegal trade crimes against protected animals in the West Kalimantan region, and analyze the performance of stakeholders in law enforcement against the illegal trade of protected animals in the West Kalimantan region based on their role and authority. This study uses survey methods or data collection by giving questionnaires to respondents. The selection of respondents by purposive sampling, data analysis using law enforcement policy analysis, descriptive analysis and tabulation analysis. The results of the study show that in the period of 2016-2019 there were 49 cases of illegal wildlife trade in West Kalimantan Province, the traded animals are species belonging to protected animals and classified in the Appendix I. category. The dominant protected species traded in the 2016-2019 period originated from anteater species (Manis javanica), Orang-utan (Pongo pygmaeus), and Turtle (Chelonia sp.). The dominant factor causing in the illegal trade of protected animals in the province of West Kalimantan in the 2016-2019 period was economic factors, followed by motives for the collection of rare goods and consumption. The performance of stakeholders in law enforcement against protected animals in the West Kalimantan region has succeeded in handling criminal cases against protected animals, all of which ended with the execution of the defendant.
\end{abstract}

Keywords: law enforcement performance, protected animals, illegal trading, stakeholders.

\section{Abstrak}

Penelitian ini dilatarbelakangi tingginya kasus perdagangan illegal satwa dilindungi di Provinsi Kalimantan Barat. Perdagangan satwa yang dilakukan cenderung pada spesies-spesies langka dan termasuk dalam daftar terancam punah. Aksi perdagangan satwa yang masih terjadi di Provinsi Kalimantan Barat mengindikasikan masih rendahnya penegakan hukum dan lemahnya pengawasan oleh pihak terkait dalam memberantas kasus perdagangan satwa yang dilindungi. Tujuan penelitian ini untuk mengkaji faktor penyebab terjadinya kejahatan perdagangan illegal terhadap satwa yang dilindungi, serta menganalisis kinerja pemangku kepentingan dalam penegakan hukum terhadap perdagangan illegal satwa yang dilindungi di wilayah Kalimantan Barat berdasarkan peran dan kewenangan. Penelitian ini menggunakan metode survei atau pengumpulan data dengan memberikan kuesioner kepada responden. Pemilihan responden dengan purposive sampling, analisis data menggunakan analisis kebijakan penegak hukum, analisis deskriptif dan analisis tabulasi. Hasil penelitian menunjukan kurun waktu 2016-2019 terdapat 49 kasus perdagangan satwa illegal di Provinsi Kalimantan Barat, satwa yang 
diperdagangkan merupakan jenis satwa yang termasuk ke dalam satwa dilindungi dan tergolong dalam kateogri Appindiks I. Satwa dilindungi dominan yang diperdagangkan pada periode 20162019 berasal dari spesies trenggiling (Manis javanica), Orang utan (Pongo pygmeus), dan Penyu (Chelonia sp.). Faktor dominan penyebab perdagangan illegal satwa dilindungi di Provinsi Kalimantan Barat dalam periode 2016-2019 adalah faktor ekonomi kemudian diikuti motif koleksi barang langka dan konsumsi. Kinerja pemangku kepentingan dalam penegakan hukum terhadap satwa yang dilindungi di wilayah Kalimantan Barat, telah berhasil menangani kasus pidana terhadap satwa dilindungi yang kesemuanya berahir dengan eksekusi kepada terdakwa.

Kata kunci: kinerja penegakan hukum, perdagangan illegal, satwa dilindungi, pemangku kepentingan.

\section{PENDAHULUAN}

Sumber daya alam hayati Indonesia dan ekosistemnya mempunyai kedudukan dan peran yang penting bagi Negara Kesatuan Republik Indonesia (NKRI). Namun kasus kejahatan perdagangan illegal satwa dilindungi masih sering terjadi di Indonesia. Salah satu provinsi di Indonesia yaitu Kalimantan Barat terjadi kasus perdagangan illegal pada periode 20162019 mencapai 49 kasus. Kasus tersebut mayoritas kasus perdagangan satwa ke luar pulau dengan skala perdagangan cukup signifikan. Kasus perdagangan lokal sangat sedikit yang dapat diungkap karena mata rantai perdagangan terputus.

Sumber daya alam hayati perlu dikelola dan dimanfaatkan secara lestari, selaras, serasi dan seimbang untuk kesejahteraan. Fatchan (2013) memperkuat bahwa sumber daya alam adalah segala sesuatu yang ada dilingkungan alam yang dapat dimanfaatkan untuk berbagai kepentingan dan kebutuhan hidup manusia agar lebih sejahtera.

Menurut pasal 1 ayat (1) dalam Undang-Undang No. 5 Tahun 1990 tentang Konservasi Sumber Daya Alam Hayati dan Ekosistemnya (UU 5/1990), sumber daya alam hayati adalah unsurunsur hayati di alam yang terdiri dari sumber daya alam nabati (tumbuhan) dan sumber daya alam hewani (satwa) yang bersama dengan unsur non hayati di sekitarnya yang secara keseluruhan membentuk ekosistem.

UU 5/1990 mengatur tentang pembatasan-pembatasan terhadap pemanfaatan sumber daya hayati dan ekosistemnya, termasuk pembatasan dalam hal pemanfaatan satwa yang dilindungi untuk tujuan perdagangan. Sebagaimana pasal 21 ayat 2 dalam UU $5 / 1990$ yang menyatakan bahwa setiap orang dilarang untuk:

a. Menangkap, melukai, membunuh, menyimpan, memiliki, memelihara, mengangkut, dan memperniagakan satwa yang dilindungi dalam keadaan hidup;

b. Menyimpan, memiliki, memelihara, mengangkut, dan memperniagakan satwa yang dilindungi dalam keadaan mati;

c. Mengeluarkan satwa yang dilindungi dari suatu tempat di Indonesia ke tempat lain di dalam atau di luar Indonesia;

d. Memperniagakan, menyimpan atau memiliki kulit, tubuh, atau bagian- 
bagian lain satwa yang dilindungi atau barang-barang yang dibuat dari bagian-bagian tersebut atau mengeluarkannya dari suatu tempat di Indonesia ke tempat lain di dalam atau di luar Indonesia;

e. Mengambil, merusak, memusnahkan, memperniagakan, menyimpan atau memiliki telur dan atau sarang satwa yang dilindungi.

Meskipun UU 5/1990 secara tegas telah mengatur sanksi pidana bagi setiap orang yang melanggar pasal 21 ayat 2 , pemanfaatan sumber daya hayati dan ekosistemnya secara berlebihan untuk tujuan perdagangan masih terjadi. Perdagangan illegal satwa dilindungi bahkan menjadi sebuah kejahatan yang terorganisir rapi, memiliki jaringan luas dan kuat serta dengan modus pemilikan, pemeliharaan, penyelundupan hewan. Perdagangan illegal satwa dilindungi dalam beberapa kasus bahkan dilakukan eksportir dengan izin resmi.

Menganalisis

kasus-kasus perdagangan illegal satwa dilindungi yang dilindungi yang telah terjadi untuk itu sangat diperlukan. Tujuannya untuk melihat dinamika perdagangan illegal yang terjadi; tren dan motif setiap kasus; kelemahan penegakan hukum maupun pemberian sanksi terhadap pelaku perdagangan. Analisa terhadap setiap kasus-kasus perdagangan illegal dapat memberikan rekomendasi terhadap arah dan strategi penguatan institusi penegak hukum; pembaharuan strategi dalam pengungkapan kasus pidana perdagangan illegal satwa dilindungi; rekomendasi kepada para pihak khususnya pemerintah dalam hal memperkuat program-program pengembangan ekonomi lokal. Motif perdagangan illegal satwa dilindungi sering kali dikaitkan dengan motif ekonomi. Penegakan hukum tanpa dibarengi program-program konkret dalam pengembangan ekonomi lokal mustahil berjalan optimal.

Penelitian bertujuan:

1. Mengkaji faktor penyebab terjadinya kejahatan perdagangan illegal satwa yang dilindungi di Provinsi Kalimantan Barat.

2. Menganalisis kinerja pemangku kepentingan sesuai peran dan wewenang dalam penegakan hukum terhadap perdagangan illegal satwa dilindungi di Provinsi Kalimantan Barat

\section{METODE PENELITIAN}

Penelitian dilaksanakan pada bulan Oktober sampai dengan Desember 2019 di Provinsi Kalimantan Barat. Metode pengumpulan data dengan studi literatur terhadap peraturan dan perundangan yang berkaitan dengan penegakan hukum terhadap kasus perdagangan satwa serta metode survei. Teknik pengumpulan data melalui survei terdiri dari wawancara dan observasi. Wawancara dilakukan dengan kuisioner yang telah disiapkan dengan tiga instansi penegak hukum, yaitu Direktorat Reskrimsus Kepolisian Daerah Provinsi Kalimantan Barat (Ditreskrimsus Polda Kalbar), Balai Pengamanan dan Pencegahan Hukum Lingkungan Hidup dan Kehutanan Wilayah Kalimantan Barat (BPPHLHK), dan Kejaksaan 
Tinggi Kalimantan Barat. Data hasil penelitian dianalisis menggunakan dua instrumen analisis yaitu analisis kebijakan penegak hukum dan analisis deskriptif dan tabulasi.

HASIL DAN PEMBAHASAN

Jumlah Kasus Perdagangan Satwa dilindungi 2016-2019 yang Ditangani Penegak Hukum Periode 2016-2019

Kasus kejahatan perdagangan illegal satwa dilindungi di Provinsi Kalimantan Barat pada periode 2016-
2019 mencapai 49 kasus. Kasus tersebut mayoritas kasus perdagangan satwa ke luar pulau dengan skala perdagangan cukup signifikan. Kasus perdagangan lokal sangat sedikit yang dapat diungkap karena mata rantai perdagangan terputus. Diperkirakan masih banyak kasus yang belum terungkap dan terbongkar untuk skala perdagangan lokal maupun luar pulau dengan jumlah yang cukup signifikan.

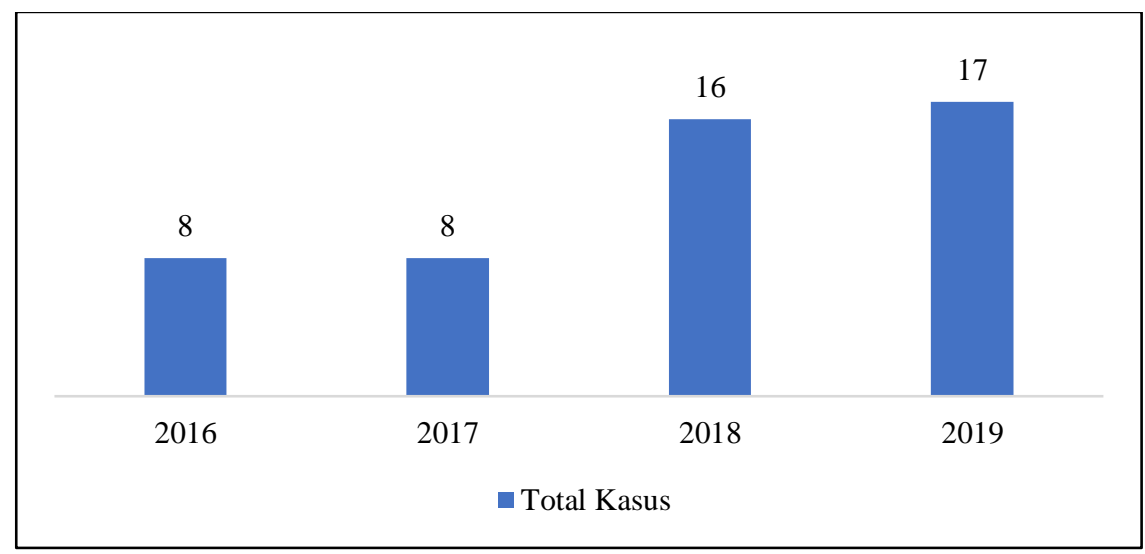

Gambar 1. Peningkatan kasus kejahatan perdagangan illegal satwa dilindungi setiap tahun pada periode 2016-2019 (Increased cases of illegal trade in protected animals every year in the 2016-2019 period)

Mengacu pada grafik di atas, pengungkapan jumlah kasus perdagangan illegal meningkat setiap tahun. Jumlah kasus pada tahun 2016 sebanyak 8 kasus. Jumlah tersebut meningkat 52 persen pada tahun 2019 menjadi 17 kasus. Kenaikan tersebut menjadi catatan penting bagi upaya konservasi satwa dilindungi bagi para pihak secara keseluruhan khususnya bagi instansi yang membidangi konservasi dan sumber daya alam. Pembaharuan strategi dan pendekatan dalam konservasi harus lebih sistematis dan komprehensif kedepan agar perlindungan satwa dilindungi dapat berjalan optimal. Model-model baru dalam pelaksanaan konservasi satwa dilindungi juga harus menjadi bagian penting dalam upaya menurunkan jumlah kasus perdagangan satwa dilindungi illegal.

Mengacu pada hasil penelitian, pengungkapan kasus (penyelidikan dan penyidikan) terhadap kasus yang terjadi dilakukan saat OTT (operasi tangkap tangan). Kasus tersebut bukan berasal dari laporan dan pengaduan masyarakat 
melainkan dari kinerja pihak berwajib atau mandiri dalam menumpas kasus perdagangan satwa illegal. Hal ini menjadi catatan penting bagi upaya penegakan hukum terhadap satwa dilindungi ke depan. Pelibatan masyarakat dapat meningkatkan jumlah penanganan kasus.

Kasus kejahatan terhadap satwa dilindungi yang ditangani penegak hukum seluruhnya masuk dalam P21 atau pemberitahuan susulan hasil penyidikan sudah lengkap. Kasus P21 menunjukan berkas perkara sudah lengkap selanjutnya masuk dalam tahap dua yaitu penyerahan tersangka dan barang bukti ke Kejaksaan. Kejaksaan akan mempelajari kasus untuk menentukan tututan hukuman sebelum dibawa ke persidangan. Kasus yang berhasil dibawa ke pengadilan menunjukan tipikal penegakan hukum terhadap kasus yang berkaitan dengan perdangangan illegal satwa dilindungi tidak sulit dibuktikan ditingkat lapangan, kecuali yang berkaitan dengan jaringan pasar. Faktor lain, tipikal kasus berada pada rantai perdagangan di tingkat bawah, dimana pelaku utama adalah masyarakat selaku penangkap dan pengepul satwa dilindungi.

Catatan kritis dari jumlah penegakan hukum kejahatan perdagangan illegal satwa dilindungi adalah pengungkapan kasus kejahatan mayoritas hanya pada pelaku di tingkat terendah. Sasaran penegakan hukum adalah mata rantai terbawah sampai dengan menengah, dimana faktor ekonomi yang menjadi alasan utama keterlibatan dalam perdagangan illegal. Rantai perdagangan tingkat atas, misalnya penadah satwa dilindungi maupun pembeli akhir di luar pulau tidak tersentuh. Keterbatasan kewenangan yang dimiliki penegak hukum di lingkup Provinsi Kalimantan Barat membuat pelaku penadah satwa dilindungi maupun pembeli akhir di luar pulau tidak tersentuh. Sinergi para penegak hukum baik di level lokal, regional, dan nasional untuk itu, menjadi sangat krusial untuk memutus mata rantai perdagangan dari tingkat terendah hingga tingkat tertinggi.

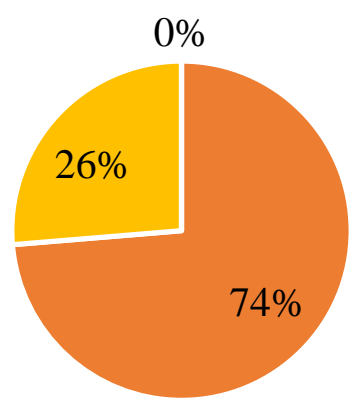

- Lokal

- Regional

- Internasional

Gambar 2. Faktor utama terjadinya kejahatan satwa yang dilindungi pada periode 2016-2019 di Provinsi Kalimantan Barat (The main factor in the occurrence of protected animal crimes in the 2016-2019 period in West Kalimantan Province) 


\section{Jenis Satwa dilindungi Yang Diperdagangkan Periode 2016-2019}

Satwa dilindungi dominan yang diperdagangkan berasal dari spesies trenggiling (Manis javanica). Jumlah kasus perdagangan Trenggiling yang berhasil diungkap penegak hukum pada periode 2016-2019 mencapai 28 kasus. Jumlah pengungkapan kasus perdagangan Trenggiling terbesar terjadi pada tahun 2018 sebanyak 15 kasus. Jumlah kasus berkurang pada tahun 2019 menjadi hanya 8 kasus. Penurunan ini perlu dianalisis lebih lanjut apakah terjadi karena kesadaran masyarakat sudah tinggi untuk konservasi Trenggiling, pengaruh efek jera dari penegakan hukum, modus perdagangan yang makin sulit untuk diungkap oleh penegak hukum, atau kinerja penegakan hukum yang tidak optimal. Perdagangan illegal menjadi ancaman besar bagi upaya konservasi satwa trenggiling (Shepherd, 2010).

Menurut analisis dari Database and Analysis Officer Wildlife Conservation Society Indonesia sebagaimana dilansir dalam https://www.mongabay.co.id/, sebanyak 26 ribu Trenggiling dari Indonesia telah diselundupkan dalam sepuluh tahun terakhir dan mayoritas dijual ke Tiongkok. Bagian yang diperjual belikan adalah sisik dan daging. Sisik trenggiling menjadi incaran utama pelaku dengan harga yang tinggi untuk dijual di pasar internasional. Adapun beberapa faktor yang mengakibatkan sisik dan daging Trenggiling menjadi satwa dominan perdangangan illegal satwa dilindungi sebagai berikut:

a. Daging, kulit, sisik, dan bagian tubuh trenggiling dipercaya berkhasiat sebagai obat tradisional bagi masyarakat Tiongkok, dan dipandang sebagai salah satu makanan yang eksotik (Zhou $d k k$., 2014). Daging Trenggiling di Afrika dijadikan makanan mewah.

b. Sisik Trenggiling terbuat dari keratin, material serupa yang membentuk kuku manusia sehingga dipercaya dapat menyembuhkan berbagai macam penyakit.

c. Harga sisik mencapai USD 3000 per kilogram dipasar internasional.

d. Trenggiling merupakan spesies yang sangat mudah diburu karena geraknya lambat dan jika naik ke atas pohon tidak bisa turun ke bawah. Bau Trenggiling yang khas juga mempermudah penangkapan dimana pemburu membawa hewan pemburu seperti anjing untuk melacak keberadaan Trenggiling.

e. Jumlah teringgiling di habitatnya diperkirakan masih banyak sehingga menjadi sasaran bagi pemburu dibandingkan dengan spesies lain. 
Tabel 1. Jenis Satwa yang Diperoleh dari Hasil Kejahatan Perdagangan Illegal terhadap Satwa Dilindungi Periode 2016-2019 (Types of Animals Obtained from the Proceeds of Illegal Trade Crime Against Protected Animals for the 2016-2019 Period)

\begin{tabular}{cccccccc}
\hline \multirow{2}{*}{ No } & \multirow{2}{*}{ Nama Satwa } & \multirow{2}{*}{ Nama Latin } & \multirow{2}{*}{ CITES } & \multicolumn{4}{c}{ Tahun } \\
\cline { 5 - 7 } & & & $\mathbf{2 0 1 6}$ & $\mathbf{2 0 1 7}$ & $\mathbf{2 0 1 8}$ & $\mathbf{2 0 1 9}$ \\
\hline 1 & Trenggling & Manis javanica & Appendiks I & 8 & 6 & 14 & 15 \\
2 & Orang utan & Pongo pygmeus & Appendiks I & - & 2 & - & - \\
3 & Penyu & Chelonia sp. & Appendiks I & - & - & 2 & - \\
4 & Kucing Kuwuk & Prionailurus bangalensis & Appendiks I & - & - & - & 2 \\
\hline
\end{tabular}

Trenggiling merupakan satwa yang banyak diperdagangkan, selain itu orangutan dan penyu merupakan satwa dilindungi lain yang diperdagangkan secara illegal yang berhasil diungkap penegak hukum selama periode 2016 sampai dengan 2019. Kasus perdagangan Orang utan diungkap pada tahun 2017 sebanyak 2 kasus dan penyu pada tahun 2018 sebanyak 2 kasus. Kasus perdagangan kucing kuwuk (Prionailurus bangalensis) sebanyak 2 kasus.

Jumlah spesies yang diperdagangkan diperkirakan lebih dari empat spesies di atas, termasuk di antaranya perdagangan paruh burung enggang (Bucerotidae, sp.), berbagai jenis burung langka dan eksotis, maupun spesies langka lain. Spesies-spesies tersebut diduga diperdagangkan secara lokal sehingga sulit untuk diungkap dan skala perdagangan kecil. Faktor lain adalah modus perdagangan yang modern sehingga meskipun skala perdagangan spesies-spesies tersebut besar, pengungkapan kasus sulit bagi penegak hukum. Diperkirakan masih banyak kasus skala besar dimana perdagangan hingga ke luar pulau yang belum dapat diungkap penegak hukum karena modus perdagangan modern dan unik.

Perdagangan illegal terhadap Orang utan lebih banyak ke tujuan penangkaran/pemeliharan secara pribadi atau individu untuk dikembangbiakan maupun prestige (status sosial). Hal ini sangat cukup berbeda dengan Trenggiling yang diperdagangkan untuk alasan pengobatan tradisional. Jumlah perdagangan orang utan yang terbatas juga dikarenakan satwa dilindungi ini sulit dibawa dalam keadaan hidup dan resiko kematian atau perawatan tinggi. Ancaman terbesar populasi orang utan berasal dari alih fungsi lahan dan kebakaran hutan serta lahan.

Sama seperti orang utan, penyu mayoritas diperdagangkan dilevel lokal. Bagian penyu yang diperdangkan adalah telur dan daging. Telur dan daging penyu diburu untuk dikonsumsi karena dipercaya memiliki khasiat tertentu. Terdapat indikasi perdagangan penyu ke luar negara dengan negara tujuan Malaysia dalam skala besar, namun sampai saat ini belum dapat diungkap secara penuh oleh penegak hukum dikarenakan data dan fakta yang terbatas. Selain tujuan konsumsi, motif pelaku dalam perdagangan penyu juga 
diduga untuk koleksi pribadi dimana penyu diawetkan sebagai barang pajangan untuk meningkatkan status sosial.

Pemerintah Indonesia telah menetapkan trenggiling, orang utan, penyu, dan beberapa spesies unik dan endemik lain sebagai satwa dilindungi dan merupakan kategori appendiks I, untuk alasan apapun, spesies-spesies tersebut tidak boleh diperdagangkan. Perdagangan illegal satwa dilindungi merupakan bisnis yang menguntungkan dengan harga jual yang tinggi. Perdagangan secara illegal (penyelundupan) menyebabkan menurunnya jumlah spesies bahkan dapat menyebabkan kepunahan jenis (Ganguly, 2013).

\section{Faktor Penyebab Kejahatan Terhadap Satwa Dilindungi}

Faktor utama yang menjadi penyebab kejahatan terhadap satwa yang di lindungi adalah faktor ekonomi, koleksi barang langka, dan konsumsi pribadi. Faktor dominan yang menjadi motif pelaku melakukan perdagangan illegal satwa dilindungi adalah faktor ekonomi. Faktor ekonomi menempati urutan pertama dengan persentase sebesar 90 persen dari total kasus yang berhasil diungkap penegak hukum selama periode 2016-2019. Faktor lain seperti koleksi barang langka dan konsumsi pribadi hanya sebesar 5 persen. Diperikaran masih ada faktor lain yang menyebabkan terjadinya perdagangan satwa seperti faktor kebudayaan, status sosial, dan lain-lain. Ketiga faktor utama tersebut diperoleh dari jumlah kasus yang berhasil diungkap penegak hukum selama periode 2016-2019.

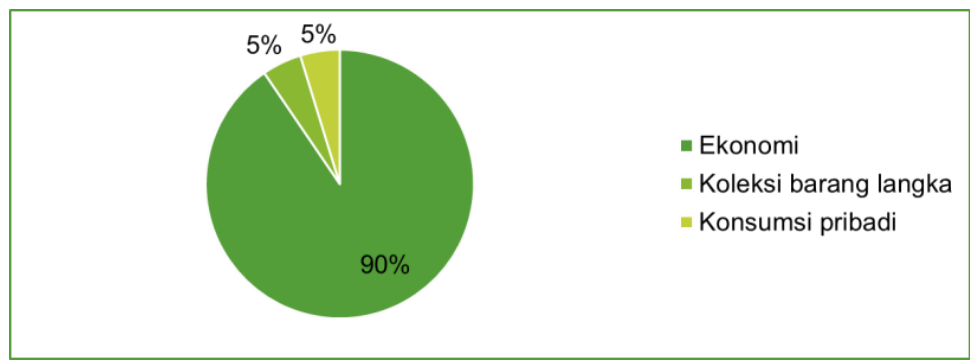

Gambar 3. Faktor utama terjadinya kejahatan perdagangan illegal satwa yang dilindungi pada periode 2016-2019 di Provinsi Kalimantan Barat (The main factor in the occurrence of illegal trade in protected animals in the 2016-2019 period in West Kalimantan Province)

Hal ini sesuai dengan pendapat Nugroho dkk (2019) yang mengatakan bahwa faktor ekonomi merupakan salah satu faktor terjadinya perdagangan satwa dilindungi secara illegal. Irawan (2014) mengatakan bahwa motif perdagangan satwa di Indonesia cenderung mengarah pada faktor ekonomi. Irawan (2014) juga menemukan motif perburuan harimau sumatera karena faktor ekonomi. Pendapat lain dikemukakan Saputra (2016) yang mengatakan faktor ekonomi 
merupakan satu di antara penyebab munculnya perdagangan satwa dilindungi di samping lemahnya sanksi yang diberikan terhadap pelaku.

Alasan faktor ekonomi menjadi dominan sebagai motif utama sebagai berikut:

a. Dari jumlah kasus yang diungkap pada periode 2016-2019, menunjukan pelaku yang ditetapkan mayoritas individu, bukan korporasi.

b. Individu yang dijadikan adalah masyarakat sebagai pemburu dan penampung di tingkat desa/kecamatan.

c. Masyarakat yang menjadi pemburu merupakan masyarakat yang berasal dari ekonomi kelas bawah sehingga cenderung ingin memperoleh keuntungan.

d. Sedangkan motif pengepul ditingkat desa/kecamatan untuk memperoleh keuntungan besar dari perdagangan. Keuntungan yang diperoleh pengepul bervariasi tergantung dari koneksi pasar yang dimiliki.

Tabel 2. Jumlah tersangka yang ditetapkan Kepolisian dan BPPHLHK pada Periode 2016-2019 (The number of suspects appointed by the Police and BPPHLHK in the 2016-2019 period)

\begin{tabular}{ccc}
\hline Tahun & Tipe Tersangka & Total \\
\hline \multirow{2}{*}{2016} & Perorangan & 8 \\
& Perusahaan & - \\
2017 & Perorangan & 8 \\
& Perusahaan & - \\
2018 & Perorangan & 16 \\
& Perusahaan & - \\
2019 & Perorangan & 17 \\
& Perusahaan & - \\
\hline & Total & $\mathbf{4 9}$ \\
\hline
\end{tabular}

Sedangkan jika tersangka yang diungkap adalah pembeli akhir, maka faktor dominan perdangan satwa dilindungi dapat berupa barang koleksi atau status sosial (perstige). Adapun tipologi tersangka dan rantai perdagangan berdasarkan informasi dari hasil pengungkapan kasus yang ditangani penegak hukum selama periode 2016-2019 sebagai berikut:

a. Pemburu. Pemburu umumnya adalah masyarakat lokal atau desa yang bermukin di sekitar/dalam maupun dari luar desa tersebut. Mayoritas pemburu yang berhasil diungkap penegak hukum merupakan pemburu yang berasal dari masyarakat lokal/desa.

b. Pengepul. Terdapat beberapa tipologi pengepul, yaitu: Pengepul di tingkat kecamatan/kabupaten adalah seseorang yang memiliki usaha misalnya toko sembako atau usaha serupa. Hasil dari buruan pemburu di desa umumnya langsung dijual ke pengepul kecamatan untuk dinilai harga dan selanjutnya ditukar dengan bahan kebutuhan pokok. Pengepul di tingkat provinsi merupakan sesorang yang memiliki akses ke 
pembeli akhir atau pengepul di tingkat internasional. Pengepul provinsi mengumpulkan dan menadah hasil buruan dari pengepul kecamatan/provinsi. Pengepul di tingkat provinsi mayoritas adalah pengusaha yang memiliki koneksi ke penegak hukum yang lebih tinggi, sehingga sulit untuk ditindak. Pengepul di tingkat internasional.

c. Pembeli. Tipologi pembeli bervariasi dan berada diberbagai level baik lokal, nasional, dan internasional. Mengacu pada praktik yang ada, tipologi pembeli ada yang bersifat pembeli akhir sementara dan pembeli akhir.

Penangkapan tersangka di rantai perdagangan tingkat atas, seperti pengepul di tingkat provinsi atau pembeli akhir satwa yang dilindungi belum pernah dilakukan dari total keseluruhan kasus yang berhasil diungkap penegak hukum. Perdagangan satwa dengan motif koleksi barang langka yang berhasil diungkap penegak hukum pada periode 2016-2019 masih berada di rantai perdagangan bawah, atau dengan kata lain pelaku perburuan dan pengepul di tingkat lokal.

Hal ini menjadi catatan penting bagi penegakan hukum kejahatan satwa dilindungi ke depan, dimana efek jera hanya berlaku bagi pelaku di tingkat bawah dan belum menyentuh pelaku ditingkat akhir perdagangan. Idealnya, penegakan hukum yang dapat memberikan efek jera secara masif adalah penegakan hukum yang mengungkap keseluruhan rantai perdagangan dari satwa dilindungi dari rantai terbawah hingga rantai teratas perdagangan. Takandjandji dan Sawitri (2016) bahwa sebanyak 52 persen kejahatan exploitasi yang terjadi karena adanya kesempatan.

Selain faktor pelaku, terdapat faktor lain yang secara signifikan mendukung terjadinya kejahatan perdagangan illegal satwa dilindungi. Faktor tersebut adalah deforestasi, konversi lahan hutan menjadi penggunaan lain, dan kebakaran hutan. Menurut Prayudhi (2015), deforestasi meyebabkan satwa kehilangan habitat aslinya, tidak jarang satwa berpindah ke lokasi yang tidak kondusif, membuatnya kekurangan sumber makanan dan meningkatkan peluang diburu untuk dimanfaatkan secara pribadi maupun diperdagangkan kembali oleh masyarakat.

\section{Jumlah Kasus yang Ditangani Masing-Masing Penegak Hukum Periode 2016-2019.}

Penegakan hukum perdagangan illegal di Provinsi Kalimantan Barat dilaksanakan Direktorat Reserse Kriminal Khusus Kepolisian Daerah Provinsi Kalimantan Barat (Ditreskrumsus Polda Kalbar), Balai Pengamanan dan Penegakan Hukum Lingkungan Hidup dan Kehutanan (BPPHLHK), Kejaksanaan, dan Pengadilan. Keempat instansi tersebut diberikan kewenangan dalam melakukan penegakan hukum kasus kejahatan perdagangan illegal satwa dilindungi di Provinsi Kalimantan Barat.

Pada periode 2016-2019, Ditreskrimsus Polda Kalbar berhasil 
melakukan pengungkapan kasus (penyelidikan dan penyidikan) sebanyak 28 kasus dan BPPHLHK sebanyak 21 kasus. Keseluruhan kasus yang ditangani Ditreskrimsus Polda Kalbar dan BPPHLHK yaitu sebanyak 49 kasus telah diserahkan ke Kejaksanaan untuk diberi tuntutan. Kejaksaan telah membawa keseluruhan kasus ke pengadilan. Setiap kasus telah memiliki vonis hukum sanksi pidana dan denda yang bervariasi dari pengadilan. Hal ini menunjukan bahwa kinerja pemangku kepentingan di dalam proses penanganan perkara (penyelidikan, penyidikan, dan penuntutan) dilaksanakan dengan baik.

Tabel 3. Jumlah Pengungkapan Kasus Kejahatan Perdagangan Illegal Satwa Dilindungi yang Ditangani Penegak Hukum Periode 2016-2019 (The Number of Disclosures of Cases of Illegal Trafficking in Protected Animals Handled by Law Enforcement Officials for the 2016-2019 Period)

\begin{tabular}{cccc}
\hline Tahun & $\begin{array}{c}\text { Ditreskrimsus Polda } \\
\text { Kalbar }\end{array}$ & BPPHLHK & Total \\
\hline 2016 & 6 & 2 & 8 \\
2017 & 3 & 5 & 8 \\
2018 & 11 & 5 & 16 \\
2019 & 8 & 9 & 17 \\
\hline Total & $\mathbf{2 8}$ & $\mathbf{2 1}$ & $\mathbf{4 9}$ \\
\hline
\end{tabular}

Payung hukum yang digunakan penegak hukum untuk mengungkap maupun mengadili kasus kejahatan perdagangan illegal satwa dilindungi mengacu pada UU No. 5/1990, KUHAP, serta regulasi teknis lain. UU 5/1990 secara tegas mengatur hal-hal yang berkaitan dengan penggunaan sumber daya alam secara berkesinambungan, pengaturan pelestarian dan konservasi flora dan fauna, ekosistem, dan wilayah lindung, serta menjelaskan bagaimana proses penyidikan, hukuman, dan sanksi bagi pelaku yang melakukan kejahatan terhadap satwa dan fauna yang dilindungi.

Pengungkapan kasus hukum yang dilakukan Ditreskrimsus Polda Kalbar dan BPPHLHK maupun tuntutan yang dilakukan Kejaksanaan di pengadilan biasanya dilakukan melalui kerjasama dan koordinasi antar ketiga instansi tersebut maupun instansi pemerintah lain seperti BKSDA Provinsi Kalimantan Barat, Dinas Lingkungan Hidup dan Kehutanan Provinsi Kalimantan Barat, dan instainsi terkait lainnya. Koordinasi merupakan suatu cara kerja yang dilakukan untuk meningkatkan hubungan baik sehingga memudahkan dalam melakukan pekerjaan, saling menjaga kepercayaan, saling mendukung dan saling menghargai dalam setiap kegiatan yang dilakukan.

Mengacu pada jumlah kasus yang berhasil diungkap kedua instansi, jumlah kasus yang ditangani Ditreskrimsus Polda Kalbar relatif lebih banyak jika dibandingkan BPPHLHK. Rasio jumlah kasus dan personil penyidik yaitu 
Ditreskrimsus Polda Kalbar terdiri dari 23 personel penyidik dengan rata-rata 7 kasus yang ditangani setiap tahunnya. BPPHLHK menangani 4 kasus pertahun dengan 10 personil penyidik. Jika dianalisis dengan prespektif peran dan fungsi kelembagaan, jumlah kasus yang ditangani BPPHLHK seharusnya lebih dominan jika dibandingkan jumlah kasus yang ditangani Ditreskrimsus Polda Kalbar. Personil penyidik BPPHLHK hanya fokus terhadap kasus-kasus kejahatan perdagangan satwa dilindungi. Penyidik Ditreskrimsus Polda Kalbar membawahi semua kasus yang berkaitan dengan tindak pidana kriminal umum di Provinsi Kalimantan Barat.

Secara yuridis, salah satu faktor yang mengakibatkan hal tersebut adalah kewenangan penangkapan tersangka. Penyidik PPNS BPPHLHK tidak memiliki wewenang untuk melakukan penangkapan dan/atau penahanan kecuali dalam hal tertangkap tangan. penangkapan atau penahanan hanya dilakukan dengan melakukan koordinasi dengan penyidik Polri. Proses hukum yang tidak sesuai setelah penangkapan atau penahanan dapat berujung pada penghentian kasus tahaptahap awal kasus. Faktor lain dalam prespektif teknis adalah penyidik PPNS BPPHLHK umumnya lebih memfokuskan pada upaya penyelamatan satwa dilindungi dibandingankan dengan meneruskan upaya hukum.

Catatan kritis dari jumlah kasus yang ditangani keseluruhan instansi diatas adalah jumlah tersebut tidak dapat dijadikan ukuran kinerja. Hal ini dikarenakan Ditreskrimsus Polda Kalbar, BPPHLHK, maupun Kejaksaan sama- sama tidak ada menetapkan ukuran untuk menilai keberhasilan dan kegagalan dalam pengungkapan kasus kejahatan satwa dilindungi. Secara rinci, catatan kritis kinerja pengungkapan kasus kejahatan satwa dilindungi yang dilakukan instansi penegak hukum sebagai berikut:

a. Parameter kinerja Kepolisian, BPPHLHK, maupun Kejaksaan tidak dapat ditentukan berdasarkan kuantitas kasus yang ditangani. Tidak ada parameter yang bisa digunakan untuk mengukur kinerja.

b. Masing-masing institusi tidak menargetkan penanganan kasus setiap tahunnya.

c. Pada saat Ditreskrimsus Polda Kalbar menangani banyak kasus perdagangan satwa, hal tersebut menjadi kinerja positif Kepolisian. Jumlah kasus yang signifikan dapat merupakan kinerja negatif bagi institusi BPPHLHK secara keseluruhan karena menunjukan upaya konservasi belum berjalan optimal

d. Jika dianalisis secara pragmatis, kinerja positif diperoleh jika ada penurunan jumlah kasus perdagangan illegal satwa dilindungi. Jumlah kasus yang terjadi periode 2016 sampai degan 2019 menandakan kinerja seluruh pemangku kepentingan dalam konservasi dan penegakan hukum masih menunjukkan tren negatif.

\section{Tantangan dalam Pengungkapan Kejahatan Satwa dilindungi}

Tantangan lain dan catatan kritis dalam penegakan hukum kejahatan satwa dilindungi selama periode 2016-2019 sebagai berikut: 
a. Terbatasnya sumber daya untuk mengawasi maupun melakukan penegakan hukum terhadap kejahatan satwa dilindungi.

b. Koordinasi yang belum optimal antara lembaga-lembaga yang berwenang.

c. Peran kelembagaan dalam menjaga wilayah konservasi masih lemah

d. Pengenalan jenis dan edukasi yang kurang dalam jenis satwa-satwa dilindungi oleh aparat penegak hukum. Claudia (2017) mengatakan kesadaran masyarakat yang rendah, maraknya perdagangan satwa illegal juga dipengaruhi oleh pengetahuan aparat penegak hukum tentang UU Perlindungan Satwa, sehingga putusan pengadilan berakhir dengan sanksi yang tidak maksimal terhadap pelaku. e. Penyidik PPNS memiliki keterbatasan dalam menyampaikan informasi kepada penyidik lainnya yang tidak memiliki keahlian dalam perdagangan satwa dilindungi.

f. Para jaksa belum sepenuhnya mengindahkan Surat Edaran dari Kejaksaan Agung No B3000/E/EJP/09/2016 tanggal 28 September 2016 yang memerintahkan hukuman berat terhadap para pelaku perdagangan illegal satwa dilindungi.

g. Penanganan terhadap suatu kasus sangat dituntut keahlian dari penyidik dalam membuka dan mengusut tuntas kasus.

Tantangan penegak hukum dalam konteks regulasi sebagai berikut:

a. Sanksi pidana kurungan dan denda diatur dalam UU 5/1990 terlalu lemah tidak ada ancaman penjara minimal.

Tabel 4. Rekapitulasi Hukuman Penjara dan Denda Tindak Pidana Terhadap Satwa Dilindungi Tahun 2016-2019 (Recapitulation of Prison Sentences and Criminal Fines Against Protected Animals 2016-2019)

\begin{tabular}{ccccc}
\hline \multirow{2}{*}{ Tahun } & \multicolumn{4}{c}{ Sanksi } \\
\cline { 2 - 5 } & \multicolumn{3}{c}{ Denda } & \multicolumn{2}{c}{ Penjara } \\
\cline { 2 - 5 } 2016 & $\leq \mathbf{5 0}$ jt & $\mathbf{5 0}-\mathbf{1 0 0}$ jt & $\mathbf{1}$ tahun & $\mathbf{1 - 5}$ tahun \\
2017 & n.a & - & - & - \\
2018 & 8 & - & 4 & 4 \\
2019 & 9 & 3 & - & 12 \\
\hline
\end{tabular}

b. UU No 5/1990 belum memperinci apabila kejahatan tersebut dilakuan secara terorganisir atau melibatkan korporasi.

c. UU 5/1990 tidak mengatur penahanan pelaku oleh penyidik BPPHLHK KLHK yang berwenang dalam menangkap pelaku perdagangan illegal satwa dilindungi. d. Sanksi pidana berupa kurungan dan denda yang diberikan terhadap kejahatan satwa yang diambil dari luar kawasan konservasi masih ringan.

e. Tidak ada dasar yang dapat digunakan penyidik ataupun jaksa untuk mengukur kerugian negara yang diakibatkan kejahatan perdagangan illegal satwa dilindungi. 
Erwin (2012) juga menambahkan penegakan hukum terhadap kejahatan di bidang kehutanan mengalami beberapa hambatan baik bersifat yuridis yang berasal dari peraturan perundangundangan yang mengatur kehutanan, maupun non yuridisnya.

\section{KESIMPULAN}

Kurun waktu 2016-2019 terdapat 49 kasus perdagangan satwa illegal di Provinsi Kalimantan Barat, satwa yang diperdagangkan merupakan jenis satwa yang termasuk ke dalam satwa dilindungi dan tergolong dalam kateogri Appindiks I.

1) Satwa dilindungi dominan yang diperdagangkan pada periode 20162019 berasal dari spesies trenggiling (Manis javanica), Orang utan (Pongo pygmaeus), Penyu (Chelonia sp.), dan Kucing Kuwuk (Prionailurus bangalensis). Jumlah spesies yang diperdagangkan diperkirakan lebih dari tiga spesies di atas namun belum dapat diungkap penegak hukum.

2) Faktor dominan yang menjadi penyebab utama terjadinya tindak kejahatan terhadap perdagangan illegal satwa dilindungi di Provinsi Kalimantan Barat dalam periode 2016-2019 adalah faktor ekonomi yaitu sebesar 90 persen, kemudiaan diikuti motif koleksi barang langka dan konsumsi masing-masing sebesar 5 persen.

3) Kinerja pemangku kepentingan dalam penegakan hukum terhadap Satwa yang dilindungi di wilayah Kalimantan Barat, telah berhasil menangani kasus pidana terhadap satwa dilindungi yang kesemuanya berahir dengan eksekusi kepada terdakwa. Catatan penting dari kinerja penegak hukum adalah tidak adanya ukuran untuk menilai keberhasilan kinerja. Masingmasing institusi penegak hukum tidak menargetkan jumlah kasus yang ditangani setiap tahunnya.

\section{SARAN}

1) Penurunan tingkat kejahatan terhadap satwa dilindungi dilindungi merupakan tanggung jawab bersama, sehingga kesadaran dan komitmen dari warga masyarakat mengenai pentingnya menjaga keanekaragaman hayati di dalam ekosistem perlu terus dibangun melaui kegiatan kampanye perlindungan satwa. Setiap elemen seperti pemerintah daerah, LSM, akademisi, bahkan dapat berpartisipasi dalam melakukan kampanye perlindungan satwa.

2) Perlu diteliti lebih lanjut mengenai model kebijakan yang tepat untuk direkomendasikan sebagai kebijakan penanggulangan kejahatan terhadap satwa dilindungi dilindungi.

\section{DAFTAR PUSTAKA}

Fatchan A. 2013. Geografi Tumbuhan dan Hewan. Yogyakarta: Ombak.

Ganguly S. 2013. Pangolin-zoological characteristics and its uniqueness in mammalian group. Journal of Entomology and Zoology Studies, 1(01): 31-32

Irawan RE, Yoserizal. 2014. Motif Perburuan Terhadap Harimau 
Sumatera Pada Kawasan Taman Nasional Bukit Tiga Puluh Kabupaten Indragiri Hulu. Jurnal Online Mahasiswa. 1 (01): 33

Nugroho AA, Subagiyo H, Fatimah I. 2019. Arah Baru Kebijakan Penegakan Hukum Konservasi Sumber Daya Alam Hayati dan Ekosistemnya. Jakarta: ICEL

Prayudhi RT. 2015. Penegakan Hukum, Rehabilitasi dan Pelepasliaran Satwa dilindungi Hasil Sitaan Negara Ujung Tombak Upaya Penstabilan Ekosistem Kawasan Konservasi.

https://www.researchgate.net/publ ication/307953979

Saputra T. 2016. Pertanggungjawaban Pidana terhadap pelaku tindak pidana perdagangan illegal satwa dilindungi yang dilindungi berdasarkan undang-undang nomor 5 tahun 1990 tentang konservasi sumber daya alam hayati dan ekosistemnya di wilayah ditreskrimsus Polda Riau. JOM Jurnal Fakultas Hukum Universitas Riau 3 (2): 32-33

Shepherd CR. 2010. Illegal primate trade in Indonesia exemplified by surveys carried out over a decade in North Sumatera. Endangered Species Research

Supardi. 2008. Hukum Lingkungan Indonesia. Jakarta: Sinar Grafika.

Takandjandji M dan Sawitri R. 2016. Analisis Penangkapan dan Perdagangan Trenggiling Jawa (Manis Javanica Desmarest, 1822) di Indonesia. Jurnal Analisis Kebijakan. 13 (12): 85-101

Zhou ZM, Zhou Y, Newman, Ch and Macdonald DW. (2014). Scaling up pangolin protection in China. Journal Environmental and Ecology Science. 2(02): 29-30 